\title{
Paulo Freire's culture circles: contributions to nursing research, teaching, and professional practice
}

\author{
Círculo de cultura de Paulo Freire: contribuições para pesquisa, ensino e prática profissional da enfermagem
}

Círculo cultural de Paulo Freire: contribuciones a la investigación, la docencia y la práctica profesional en enfermería

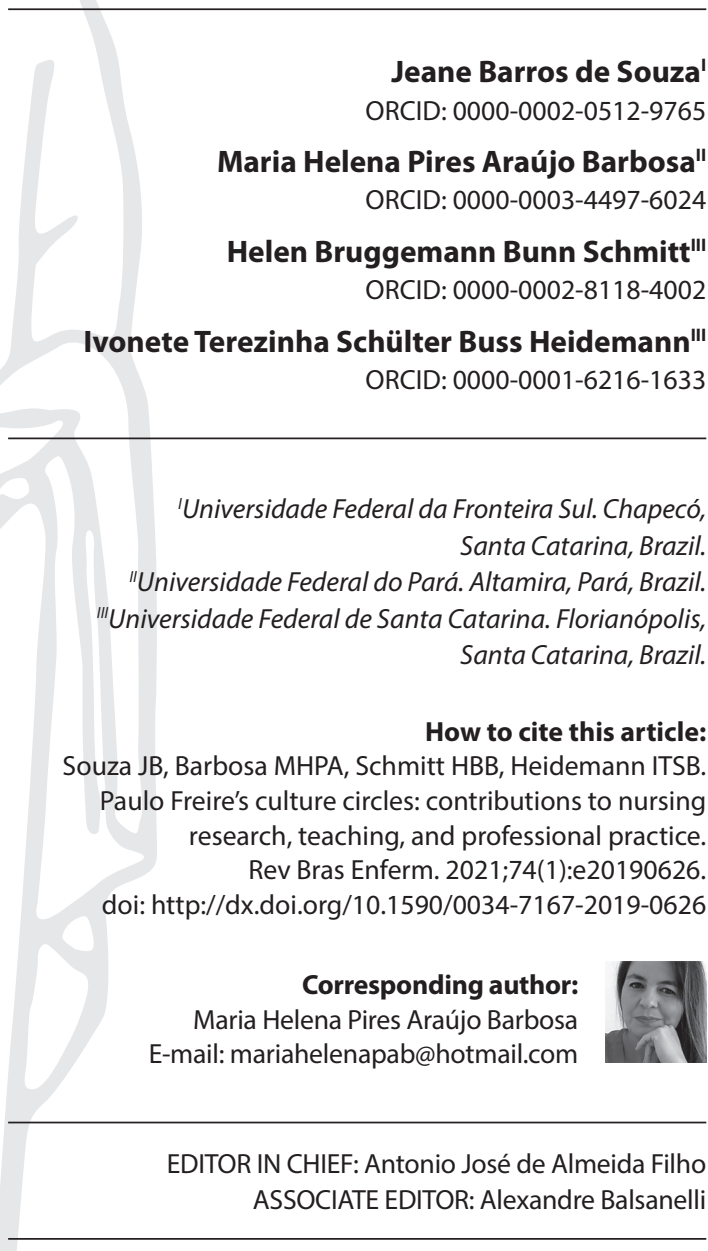

Submission: 12-07-2019
Approval: 09-15-2020

\section{ABSTRACT}

Objectives: to share the contributions of culture circles for teaching, research, and professional nursing practice, having as framework Paulo Freire's Research Itinerary. Methods: this is an experience report of a culture circle, with participation of three professors and ten students, enrolled in a course of a Graduate Program in Nursing in southern Brazil. In this culture circle, a tree was built in which the roots formed the thematic investigation, the stem, coding and decoding, and the leaves, the Research Itinerary critical unveiling. Results: participants demonstrated empowerment of Paulo Freire's assumptions, and building a tree made it possible to discuss in a pleasant and playful way culture circle use in teaching, research, and professional nursing practice. Final Considerations: the culture circle promoted reflection and action on nursing praxis, turning Freirean thoughts into something concrete and transforming realities.

Descriptors: Nursing; Nursing Research; Professional Practice; Professional Practice; Culture Circle.

\section{RESUMO}

Objetivos: compartilhar sobre as contribuições do círculo de cultura para o ensino, pesquisa e prática profissional da enfermagem, tendo como referencial o Itinerário de Pesquisa freireano. Métodos: relato de experiência de um círculo de cultura, com a participação de três docentes e dez discentes, matriculados em uma disciplina de um Programa de Pós-Graduação em Enfermagem no sul do Brasil. No círculo de cultura, foi construída uma árvore em que as raízes formaram a investigação temática, o caule, codificação e decodificação, e as folhas, o desvelamento crítico do Itinerário de Pesquisa. Resultados: os participantes demonstraram empoderamento dos pressupostos freireanos, e a construção da árvore possibilitou discutir, de maneira prazerosa e lúdica, a utilização do círculo de cultura no ensino, pesquisa e prática profissional da enfermagem. Considerações Finais: o círculo de cultura promoveu reflexão e ação sobre a práxis da enfermagem, tornando os pensamentos freireanos em algo concreto e transformador de realidades.

Descritores: Enfermagem; Pesquisa em Enfermagem; Ensino de Enfermagem; Prática Profissional; Círculo de Cultura.

\section{RESUMEN}

Objetivos: compartir acerca de las contribuciones del círculo cultural a la docencia, la investigación y la práctica profesional de la enfermería, tomando como referencia el Itinerario de Investigación Freireano. Métodos: relato de experiencia de un círculo cultural, con la participación de tres profesores y diez estudiantes, matriculados en una disciplina de un Posgrado en Enfermería en el sur de Brasil. En el círculo cultural se construyó un árbol en el que las raíces formaron la investigación temática, el tallo, codificación y decodificación, y las hojas, la develación crítica del Itinerario de Investigación. Resultados: los participantes demostraron empoderamiento de los supuestos freireanos, y la construcción del árbol permitió discutir, de manera amena y lúdica, el uso del círculo cultural en la docencia, la investigación y la práctica profesional de enfermería. Consideraciones Finales: el círculo cultural promovió la reflexión y la acción sobre la praxis de la enfermería, convirtiendo el pensamiento freireano en algo concreto y transformando realidades.

Descriptores: Enfermería; Investigacíon en Enfermería; Educación en Enfermería; Práctica Profesional; Circulo Cultural. 


\section{INTRODUCTION}

Nursing faces challenges that need to be reflected, as nursing training strongly influences their professional practice. Nursing can contribute to reproduce the biologicist, clinical and individual model or to a model based on comprehensive care, which considers individuals' socio-historical and cultural needs. Therefore, pedagogical processes, professors, and educating action in nursing teaching have an impact on professional practice ${ }^{(1)}$.

With regard to the teaching and research dimension, i.e., teaching, it is important to reflect that nurses generally become professors from their care practice, having little or no pedagogical training for this ${ }^{(2-3)}$. Professional training in nursing does not offer specific preparation for acting as a professor, which highlights a need to invest in professional training for professors. In this context, many nurse professors seek to replicate professors' actions who were outstanding in their academic journey, in order to seek success in teaching-learning ${ }^{(2)}$.

Considering the challenges in professional practice to work at Unified Health System (SUS - Sistema Único de Saúde), nursing has been appropriating Paulo Freire's thoughts, in search of new teaching models that respond to profession's desires and that enable qualification in academic training. In nursing research, Paulo Freire's assumptions, through the applicability of participatory studies, have provided advances in the involvement of society and performance of subjects, who are the true authors and conductors of research that, in a logical sequence of research actions, bring together interests both academic and social ${ }^{(4)}$.

In this regard, it is important to bring subjects together through dialogue, proposing autonomy and reflections in the face of concrete situations of existence, not excluding the different experiences and knowledge, but valuing contradictions and trying to overcome and work them out. Thus, according to Paulo Freire's assumption, it is necessary "subject empowerment", which is the "liberation of the oppressed"(4). But dialogue, be it between professor and student, or between nurse and user, or between the interprofessional team needs to be horizontalized. There is no one who knows more or understands less, but different knowledge that needs to be shared, with a responsibility in those who are in the role of teaching/learning, because educating is a political act ${ }^{(5)}$.

The political facet of educating appears when subjects critically analyze their life, their reality and their problems, which leads to transformation. Paulo Freire's criticism of banking education translated into understanding that each one has knowledge, not being a blank page to be shaped, an emptiness where a professor deposits what needs to be memorized and reproduced. In short, education needs to be emancipatory, loving, libertarian, achieved through participation, with consequent empowerment ${ }^{(5-6)}$.

To this end, Paulo Freire thought of an itinerary to elaborate this shared knowledge, because he did not like to think about method, starting from the present and concrete situation, in order to reflect the situations involving subjects and organize the programmatic content of education or political action, proposing, through certain basic contradictions, their existential situation as a problem that challenges it and that requires intellectual and practical responses ${ }^{(6)}$. Research Itinerary comprises three different phases, which are dialectically interconnected, namely: thematic research; coding and decoding; critical unveiling, in which there is a systematic and interdisciplinary reflection of the knowledge emerging in the process, receiving the most diverse approaches, such as sociology, political science, and social psychology ${ }^{(4,6)}$.

Paulo Freire's Research Itinerary, full of his concepts and thoughts, can be a methodological option. Culture circles arise from the possibility of helping subjects to understand their reality through their experience and exchange of knowledge in a space in which different beings and practices pass, in which participants take on the experience of dialogue in search of discussing their problems and planning concrete actions of collective interest ${ }^{(4)}$.

\section{OBJECTIVES}

To share the contributions of culture circles for teaching, research, and professional nursing practice, having as reference Paulo Freire's Research Itinerary.

\section{METHODOLOGICAL PATH}

All professors and students involved in a Graduate Nursing Program course in southern Brazil in June 2019 participated in the culture circle. This course addressed the theoretical and philosophical foundations of Paulo Freire's thought. Participants were nurses, three professors and ten Master's or PhD students in nursing. Among student nurses there were scholarship holders and others who worked in health services. The culture circle took place in the university space itself, in the classroom where the mentioned course was developed, lasting approximately two hours.

In order to dialogue and reflect on culture circles, Paulo Freire's Research Itinerary was followed, which presents thematic investigation, coding and decoding, and critical unveiling ${ }^{(7-8)}$. The framework of Paulo Freire's thought was used, which as a Brazilian professor boosted the strengthening of criticality in the teaching-learning process $s^{(4)}$, which occurs from praxis, which is the reflection and action of men on the world to transform it. It is theory and practice, but without verbalisms and activism, but with reflection and action on the organizations to be modified ${ }^{(7)}$. Several concepts permeate Paulo Freire's works, among them are culture circles, awareness, praxis, and banking/liberating education ${ }^{(7-8)}$.

To do so, Paulo Freire's Research Itinerary scheme was used, based on an adaptation prepared by the authors, who systematized the stages by building a reflective tree, as shown in Figure 1.

The idea of building a reflective tree arose from the need to make the discussion about culture circles more concrete, creative, interactive, and dialogical. This made it possible to carry out all Research Itinerary stages in a single meeting. For this, the base of a paper tree was built, which was exposed on the floor of the classroom, in the center of the circle composed by participants, so that everyone could see it. 


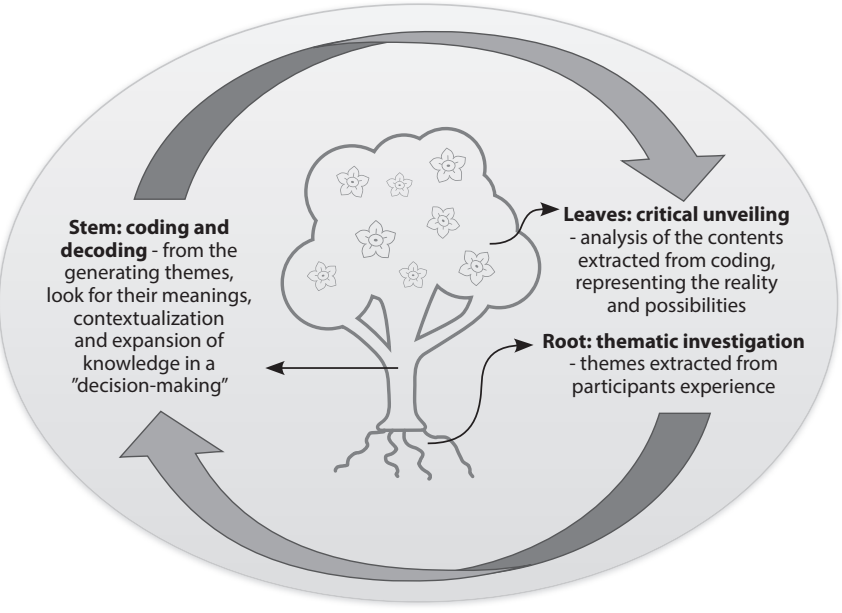

Figure 1 - Paulo Freire's Research itinerary in building a reflective tree

\section{Birth of roots: thematic investigation}

The roots help to firm the tree to the ground and are responsible for the absorption of essential substances, such as water and mineral salts. Moreover, in general, there is a primary root and several branches that are the lateral roots ${ }^{(9)}$. The roots were elaborated from the experiences previously reported by participants via e-mail. Students and professors were asked to write a brief report on their experiences with the culture circles in nursing, without making any previous comment on the subject on this subject. A week before the meeting, the reports sent by e-mail were read and organized by the culture circle mediator, reflecting on three major themes: culture circles, dialogue, and problem-based learning.

The three great roots were presented at the beginning of the meeting to participants, describing the three themes. Then, small roots of paper describing a term taken from the reports sent by email were distributed to the group. Each subject was invited to place these on top of the main roots, exposed to the ground, in order to describe them, organize and validate the themes during the thematic research phase, in which everyone discussed together about the ideal place for each term to be, for a better definition of the three roots (themes).

However, the group realized that important words/terms were still missing to describe the three roots; other roles were given opportunities with the small roots not filled in, so that they could transcribe, so that everyone would feel represented in the three themes that addressed the experiences of culture circles in nursing. After extensive discussion, the three main roots were represented as follows:

- Problem-based learning: context, autonomy, oppressoroppressed, active participation, empowerment, ethics, shared space, leadership, facilitator/mediator, professor/student.

- Dialogue: criticality, respect, reciprocity, reflection, debate, loving, resoluteness, opinion, horizontality and organization.

- Culture circles: organization, different knowledge, joint definition, action-reflection-action, liberation, thinking, teachinglearning, group of people and sharing.

It is important to note that the group was unable to insert four words in just a single root. From then on, after discussion, they decided to put them transversally in the roots, because they believed that they all crossed the three themes: emancipation, transformation, awareness-raising, and culture.

It should also be noted that the thematic research was guided by dialogic model and liberating education, in which the generating themes were discussed and the critical-reflective thinking of participants could be widely shared ${ }^{(6,8)}$. Thus, the meeting became a dynamic learning space that enabled reflection on existential situations.

\section{Dialogical reflections on stem building: coding and decoding}

The coding stage, which is not dissociated from decoding, inaugurated the Research Itinerary's second phase, in which coding the generating themes contemplated the contradictions and representations of the situations experienced by participants ${ }^{(6-7)}$. Upon entering decoding and in the course of dialogue among participants, there was recognition of reality and awareness based on the reflection of actions, considering themselves as beings capable of transforming the world ${ }^{(7)}$ of nursing.

To carry out the coding and decoding stage, the strategy of building a reflective tree stem was used. The stem supports the plant and transports the nutrients produced in photosynthesis, from the leaves to the roots. Plant hormones are produced in the stem, aiding growth and development ${ }^{(9)}$. In the same sense, it was decided to divide the stem into three parts, for the development of coding and decoding, in order to seek the meanings and expand the knowledge of the generating themes, organized in the roots of the tree. To instigate dialogue, three guiding questions were asked, one for each part of the stem: 1) How can culture circles contribute to teaching in nursing? 2) How can culture circles contribute to nursing research? 3) How can culture circles contribute to professional practice of nursing?

For stem building, participants were divided into small groups by means of a lottery, in which the mediator gathered all the members who took the same number in one group, leaving a total of three groups, containing four participants in each. This allowed everyone to be involved in the process, taking care to keep one professor in each group. The mediator did not participate in any specific way in any group in order to conduct the proposed activities. Each group stayed for approximately 10 minutes in each part of the stem, discussing and making notes concerning the guiding questions of the parts of the stem. Upon hearing a musical sound, participants of each group were invited to go to the other part of the stem and debate about another guiding question.

All groups went through the three parts of the stem, leaving their perceptions about the contributions of culture circles to the world of nursing. At the end of the allotted time, the groups socialized the discussions raised. After presentation of each group, the pieces of the reflective tree stem were being assembled on the ground, organized and discussed by the culture circle's participants.

Building the reflective tree stem started from the concrete existential situation (coding), on the contributions of culture circles applied to teaching, research and professional nursing practice, allowing participants to carry out analysis of praxis and obtain 
new knowledge (decoding) ${ }^{(6)}$. This building was permeated by dialogue and awareness, since they must be the foundation of educational practice that uses Paulo Freire's theoretical-methodological framework.

In the first part of the stem, nursing education was discussed. The group defined that culture circles allow participants' critical reflection, involving professors and students, professor and educating in teaching-learning, in an exchange of knowledge, aiming at the formation/building/expansion of knowledge and respecting the diversity and autonomy of subjects involved. From then on, professors and students can be transformed through the practice of dialogical action. Professors are considered to be mediators in the teaching-learning process and learn together with learners. Students are not a deposit to be filled by professors, but that together they can learn and discover new possibilities in the reality of life ${ }^{(7)}$.

The second part of the stem made it possible to reflect on the culture circles in nursing research. For the group, culture circles provide innovation and improvements for nursing research. They make it possible not only to research, but also to transform reality through participatory research, reaching the individual's and the collective's real needs, leaving seeds for reflection for the actors involved in the action research process. Furthermore, culture circle use in qualitative participatory research enables a direction when following the Research Itinerary stages, with a liberating and emancipatory nature, expanding the reflection process not only of the researcher, but of all participants.

The third part of the stem was intended to discuss culture circles in the context of professional nursing practice. The group highlighted that culture circles in nursing practice both in the hospital and in Primary Health Care promote interprofessionality. They pointed out that they enable the participation of all the team's professionals, in which they learn from each other and from each other to discuss improvements for the health of individuals and communities together. The experience of interaction through interprofessionality is recognized as a promoter of skill development for collaborative practice ${ }^{(10)}$. They also argued that culture circles make horizontality possible, by respecting different knowledge through the exchange of knowledge in dialogical action. It was also shown that horizontality in the practice of nursing must exist between professional and user, respecting their practices and knowledge, guaranteeing autonomy, in a humanized, sensitive and empathic care.

\section{Leaf creation: critical unveiling}

The Research Itinerary's last stage is critical unveiling, which aims to overcome the magical vision and develop a critical reality with a view to transforming action ${ }^{(6,8)}$. In this stage, participants built the reflective tree's canopy using paper in the shape of leaves.

In order for participants to build the canopy, paper sheets were distributed and everyone was invited to write about the meanings of culture circles. Subsequently, each subject presented the meaning described on the leaf and inserted it in the canopy of the reflective tree. Then the following meanings emerged: transformation; important research "method"; dialogue; personal and professional growth; going beyond; evolution; exchanging knowledge; action - reflection - action; thematic investigation, coding - decoding, critical unveiling; meeting different people and different knowledge; reflection and transformation of reality. Subsequently, the stages of Paulo Freire's Research Itinerary were presented to the group and participants could understand the moments experienced in culture circles.

The leaf is the part of the plant responsible for carrying out photosynthesis, which is the process by which the plant produces its own food. Breathing and sweating also occur in the leaves. These two processes are possible because on the leaf surface there are structures that open and close, allowing the entry and exit of gases and water from the plant ${ }^{(9)}$. In the same way, there was a critical unveiling, in which everyone fed back on the reflections in the group and individually they were able to open, close and open themselves again to new knowledge, new foods. Thus, they left the experience transformed and empowered over culture circles, with the desire to germinate new seeds in other soils in the world of nursing.

During the critical unveiling stage, the researcher must be a mediator to assist the process of understanding reality, with an critical eye of participants, with a view to transforming action ${ }^{(8)}$. Thus, there is awareness of the existential situation and the limits and possibilities of reality are unveiled. To close Paulo Freire's Research Itinerary, an evaluation of the experience must be carried out so that the changes perceived by participants are clarified ${ }^{(6)}$.

In this regard, when finishing building a reflective tree, participants were encouraged to evaluate and share the meanings of culture circles experience. They reflected on having been a space for mutual learning, discussion, dialogue, exchange of experiences, (re) knowledge of the different nursing settings, as well as on the various facets and applicability of Freire's culture circles. They also shared that they had the opportunity to learn in a practical way, with each other, about the stages of Paulo Freire's Research Itinerary, becoming something more concrete and interactive through the playfulness of building a reflective tree, which instigated them to think collectively, but considering and respecting the individual knowledge of each participant.

\section{FINAL CONSIDERATIONS}

Culture circles made it possible for us to dialogue and reflect on the nursing praxis about teaching, research and professional practice. We identified, together with the participating group, that despite the limited experience in the culture circles, fruits were revealed. Various seeds have evolved when reading texts on the Freirean theme, which motivated the empowerment on the subject and the active participation in dialogues for building a reflective tree.

Participants revealed that the culture circles contribute to the nursing teaching process by enabling critical reflection between professor and student. In this movement, knowledge sharing occurs, valuing students' autonomy, and professors are also transformed by the praxis of dialogic action.

In reflecting on research in nursing, participants pointed out that the culture circles make it possible to conduct research, but it also contributes to the transformation of reality. Through Research Itinerary, it is possible to understand individuals' and 
the collective' real needs, especially in the case of qualitative research of the participatory type, which promotes participation of all those involved.

When discussing professional practice of nursing both in Primary Health Care and hospital, it was discussed that culture circles promote horizontality, dialogue with sharing of knowledge between nurses and users in an interprofessional way. Culture circles respects practices and knowledge, guaranteeing autonomy in humanized, emancipatory, empathic and transformative care. When paraphrasing Paulo Freire, it can be said that to overcome the challenges of nursing it is necessary to transform nurses' thinking, oppressed, and not the situation that oppresses them.
Thus, building a reflective tree made it possible to discuss lovingly, in a pleasant and playful way about culture circle use in nursing, through Paulo Freire's theoretical-philosophical thinking, as a possibility for transforming reality. This experience provided a critical reading of knowledge and practices, bringing mature fruits of knowledge and rich in beauty and possibilities for professors and students involved in the process. The seeds are found inside the fruits; therefore, it is expected that the seeds sown in the sharing of this experience can find appropriate conditions, and thus germinate in other soils and originate new research and experiences that discuss Paulo Freire's culture circle use in nursing and health.

\section{REFERENCES}

1. Mattia BJ, Kleba ME, Prado ML. Nursing training and professional practice: an integrative review of literature. Rev Bras Enferm. 2018;71(4):2039-49. doi: 10.1590/0034-7167-2016-0504

2. Fernandes CNS, Souza MCBM. Docência no ensino superior em enfermagem e constituição identitária: ingresso, trajetória e permanência. Rev Gaúcha Enferm. 2017;38(1):e64495. doi: 10.1590/1983-1447.2017.01.64495

3. Correa AK, Sordi MRL. Educação profissional técnica de nível médio no Sistema Único de Saúde e a política de formação de professores. Texto Contexto Enferm. 2018;27(1):e2100016. doi: 10.1590/0104-07072018002100016.

4. Waterkemper R, Prado ML, Reibnitz KS. Paulo Freire: ideias que desacomodam. In: Prado ML, Schmidt KR. Paulo Freire: a boniteza de ensinar e aprender na saúde. Florianópolis: NFR/UFSC; 2016. 195 p.

5. Streck DR, Redin E, Zitkoski JJ. Dicionário Paulo Freire. 4 ed. Belo Horizonte: Autêntica Editora; 2018. 512 p.

6. Heidemann ITSB, Dalmolin IS, Rumor PCF, Cypriano CC, Costa MFBNA, Durand MK. Reflexões sobre o itinerário de pesquisa de Paulo Freire: contribuições para a saúde. Texto Contexto Enferm. 2017;26(4):e0680017. doi: 10.1590/0104-07072017000680017

7. Freire P. Pedagogia do Oprimido. 67 ed. Rio de Janeiro: Paz e Terra, 2019. 256 p.

8. Garzon AMM, Silva KL, Marques RC. Liberating critical pedagogy of Paulo Freire in the scientific production of Nursing 1990-2017. Rev Bras Enferm. 2018;71(Suppl 4):1751-8. [Thematic issue: Education and teaching in Nursing] doi: 10.1590/0034-7167-2017-0699

9. Crichyno J. Árvore e imaginário simbólico como lugar poético de memória na paisagem. Rev NUFEN [Internet]. 2017 [cited 2020 Sep 09];9(2):124-37. Available from: http://pepsic.bvsalud.org/scielo.php?script=sci_arttext\&pid=S2175-25912017000200009

10. Batista NA, Batista SHSS. Educação interprofissional na formação em Saúde: tecendo redes de práticas e saberes. Interface. 2016;20(56):2024. doi: 10.1590/1807-57622015.0388 